\title{
A systematic review of the use of computers in the management of hypertension
}

\author{
Alan A Montgomery, Tom Fahey
}

\begin{abstract}
Study objective-To assess the effect of computers and computer-based clinical decision support systems on the management of hypertension.

Design-Systematic review of randomised controlled trials.

Setting-Ambulatory hypertension clinics, community-based health centres, and general practices.

Participants-11 962 patients enrolled in seven trials retrieved from a systematic search (electronic databases, contact with authors, reference lists; no restriction on language).

Main results-Individual trials report on a diverse population of patients (newly diagnosed or established hypertensive patients), interventions (computers used for case finding, recall and registration, feedback on quality of blood pressure control and prescribing information), and outcomes (administration, physician performance and blood pressure control). Four of five trials reported an improvement in patient administration using a computer. Two of three trials reported an improvement in physician performance using a computer. Two of six trials reported an improvement in blood pressure control in patients using a computer. However, positive findings in two trials should be regarded cautiously because of the potential effects of cluster randomisation.
\end{abstract}

Conclusions-It seems that computers have a favourable effect on the uptake and follow up of patients in hypertension management. The effect of computers on physician knowledge, recording of information, and blood pressure control in patients is less conclusive and further studies are required.

(F Epidemiol Community Health 1998;52:520-525)

Hypertension (high blood pressure) is a major contributor to cardiovascular morbidity and mortality. ${ }^{1}$ However, inadequate detection and control of hypertension in the community still remains a problem. ${ }^{2}$ The role of other factors in the overall assessment of cardiovascular risk is now acknowledged. ${ }^{3}$ Explicit risk stratification based on absolute risk assessment has been incorporated into hypertension guidelines, ${ }^{4}$ and requires that blood pressure and other cardiovascular risk factors need to be considered and modified.

Computer use is very common in general practice and is likely to increase as computers become more sophisticated. Around $80 \%$ of general practices were computerised in 1993, and this was predicted to rise to $92 \%$ by $1997 .{ }^{5}$ Efficient case finding, registration, recall, and review are recognised as central to effective management of high blood pressure in the community. ${ }^{6}$ These tasks are all readily facilitated by computers. Computers can also help with the prescribing of antihypertensive treatment in terms of dose, interactions, and compliance.

The use of computer-based clinical decision support systems (CDSSs) is expanding ${ }^{7}$ and computers and CDSSs have been shown to improve the process and outcome of clinical care.$^{8}{ }^{9}$ In addition clinical guidelines, in either written or computerised format improve preventive and clinical care, and prescribing and support services. ${ }^{10}$ Computers have the potential to make risk stratification easier and more accessible to doctors and patients during the consultation. For all these reasons computers are likely to play a more important part in the detection, treatment, and follow up of hypertension in the community.

We decided to perform a systematic review of all randomised controlled trials that evaluated the use of computers in the detection and management of high blood pressure in either community or hospital-based ambulatory settings.

\section{Methods}

INCLUSION CRITERIA

We included randomised controlled trials of the use of computers and CDSSs that investigated any dimension of the administration or management of hypertension. A CDSS was defined as an active knowledge system that uses two or more items of patient data to generate case specific advice. ${ }^{9}$ Hypertension was defined according to criteria used in five sets of guidelines. ${ }^{41-14}$ The outcomes measured in this review were: (a) patient uptake/ administration (initial and follow up measurement of blood pressure in patients); (b) physician performance (knowledge and recording of information); and (c) blood pressure control achieved in hypertensive patients (control according to criteria used in primary studies).

\section{STUDY IDENTIFICATION}

We searched the computerised databases of the Cochrane Library (1997 Issue 3), Medline (1966-1997), BIDS science citation index (1981-1997), and EMBASE (Excerpta Medica, 1980-1997) using the recommended Cochrane search strategy ${ }^{15}$ including the following Medical Subject Heading (MESH) 
Table 1 Summary of seven randomised controlled trials that examined the use of computers in the detection and management of high blood pressure (see Results for fuller description of outcomes assessed)

\begin{tabular}{|c|c|c|c|c|c|c|c|}
\hline Trial & Year & $\begin{array}{l}\text { Trial } \\
\text { quality }\end{array}$ & Setting & Health professionals & $\begin{array}{l}\text { Number of } \\
\text { subjects }\end{array}$ & Inclusion criteria & Subject characteristics \\
\hline McDowell $^{17}$ & 1989 & 6 & $\begin{array}{l}6 \text { practices in } \\
\text { hospital affiliated } \\
\text { family medicine } \\
\text { centre in Canada }\end{array}$ & $\begin{array}{l}6 \text { staff physicians } \\
6 \text { nurses } \\
\text { family medicine } \\
\text { residents } \\
\text { (number not } \\
\text { stated) }\end{array}$ & 8298 & $\begin{array}{l}1 \text { Adults aged } 18 \text { and over } \\
2 \text { No BP recorded in preceding } 12 \\
\text { months }\end{array}$ & $\begin{array}{l}56.5 \% \text { female, mean age } 44.5 \\
\text { years, all white, } 54.6 \% \text { married }\end{array}$ \\
\hline Dickinson $^{18}$ & 1981 & 8 & $\begin{array}{l}4 \text { practices in } \\
\text { family medicine } \\
\text { centre in USA }\end{array}$ & $\begin{array}{l}4 \text { faculty } \\
\text { physicians } \\
37 \text { residents }\end{array}$ & 250 & $\begin{array}{l}1 \text { Hypertensive patients visiting } \\
\text { practice during } 4 \text { month baseline } \\
\text { period } \\
2 \text { Increased systolic or diastolic } \\
\text { pressure at last baseline visit } \\
3 \text { At least one visit during } 7 \text { month } \\
\text { intervention period }\end{array}$ & $\begin{array}{l}69.9 \% \text { female, mean age } 49.6 \\
\text { years, } 70.4 \% \text { white } \\
\text { mean weight } 78.9 \mathrm{~kg} \text {, mean } \\
\text { baseline BP } 159 / 89 \mathrm{~mm} \mathrm{Hg}\end{array}$ \\
\hline Barnett $^{19}$ & 1983 & 6 & $\begin{array}{l}1 \\
\text { community-based } \\
\text { health centre in } \\
\text { USA }\end{array}$ & $\begin{array}{l}\text { physicians } \\
\text { nurse-practitioners } \\
\text { numbers not } \\
\text { stated }\end{array}$ & 115 & $\begin{array}{l}1 \text { Sustained hypertension and/or } \\
\text { diagnosis of hypertension and } \\
\text { placed on therapy } \\
2<2 \text { repeat BP measurements after } \\
\text { initial visit }\end{array}$ & $\begin{array}{l}49 \% \text { female, mean age } 43 \text { years } \\
(42 \% \text { older than } 45 \text { years), } \\
17 \% \text { black, mean initial BP } \\
150 / 102 \mathrm{~mm} \mathrm{Hg}, 7 \% \text { with } \\
\text { history of hypertension, } 4 \% \\
\text { with history of cardiovascular } \\
\text { disease, } 15 \% \text { with family } \\
\text { history of hypertension, } 34 \% \\
\text { diagnosed obese }\end{array}$ \\
\hline McAlister $^{20}$ & 1986 & 6 & $\begin{array}{l}60 \text { family doctors } \\
\text { in single handed } \\
\text { practices in } \\
\text { Canada }\end{array}$ & $\begin{array}{l}60 \text { family } \\
\text { physicians }\end{array}$ & 2331 & $\begin{array}{l}\text { Analysed by } 4 \text { groups based on } \\
\text { baseline diastolic BP measurement: } \\
1>90 \mathrm{~mm} \mathrm{Hg} \text { or antihypertensive } \\
\text { medication at any time } 291-104 \\
\text { mm Hg ('mild' hypertension) } 3 \\
>104 \mathrm{~mm} \mathrm{Hg} \text { ('moderate' } \\
\text { hypertension) } 4 \text { All patients with } \\
\text { newly detected hypertension during } \\
\text { trial }\end{array}$ & $\begin{array}{l}\text { computer group: } 53.3 \% \\
\text { female, mean age } 59.8 \text { years } \\
\text { control group: } 64.2 \% \text { female, } \\
\text { mean age } 57.7 \text { years }\end{array}$ \\
\hline $\begin{array}{l}\text { van den } \\
\text { Hoogen }^{21}\end{array}$ & 1990 & 8 & $\begin{array}{l}15 \text { general } \\
\text { practices in the } \\
\text { Netherlands }\end{array}$ & $\begin{array}{l}\text { general } \\
\text { practitioners } \\
\text { (number not } \\
\text { stated) }\end{array}$ & 574 & $\begin{array}{l}1 \text { Newly detected hypertension in } \\
\text { two years prior to study } \\
2 \text { Aged } 36-55 \text { years }\end{array}$ & no information given \\
\hline Bulpitt $^{22}$ & 1976 & 6 & $\begin{array}{l}3 \text { hospital } \\
\text { hypertension } \\
\text { clinics in UK }\end{array}$ & $\begin{array}{l}\text { hospital physicians } \\
\text { (number not } \\
\text { stated) }\end{array}$ & 278 & $\begin{array}{l}\text { All patients with diagnosed } \\
\text { hypertension referred to clinics until } \\
\text { target numbers reached }\end{array}$ & $\begin{array}{l}\text { computer group: } 56 \% \text { female, } \\
\text { mean age } 51 \text { years, mean lying } \\
\text { BP } 178 / 105 \mathrm{~mm} \mathrm{Hg} \\
\text { control group: } 53 \% \text { female, } \\
\text { mean age } 48 \text { years, mean lying } \\
\text { BP } 177 / 106 \mathrm{~mm} \mathrm{Hg}\end{array}$ \\
\hline $\mathrm{Coe}^{23}$ & 1977 & 8 & $\begin{array}{l}2 \text { hospital } \\
\text { hypertension } \\
\text { clinics in USA }\end{array}$ & $\begin{array}{l}\text { hospital physicians } \\
\text { (number not } \\
\text { stated) }\end{array}$ & 116 & $\begin{array}{l}1 \text { Mean of } 3 \text { separate pretreatment } \\
\mathrm{BP} \text { measurements }>140 / 95 \mathrm{~mm} \mathrm{Hg} \\
2 \text { Three return visits while on } \\
\text { treatment } \\
3 \mathrm{BP} \text { medication taken as prescribed }\end{array}$ & $\begin{array}{l}90.5 \% \text { female, mean age } 52 \\
\text { years, all black, unselected } \\
\text { consecutive referrals to clinics } \\
\text { during } 6 \text { month period }\end{array}$ \\
\hline
\end{tabular}

$\mathrm{N} / \mathrm{A}=$ not assessed

terms: “computers", “microcomputers", "computer assisted therapy", "ambulatory care", "information system", "expert systems", "hypertension", "blood pressure", "blood pressure determination", and "mass screening". We also did a citation search of previous reviews on the subject and of studies identified in the search, and we wrote to all authors requesting information about unpublished trials, additional data, and clarification of data when necessary. The search included studies published in non-English language journals. We were interested in randomised controlled trials that allocated patients, GPs or practices to computer interventions according to a random or quasi-random schedule.

\section{STUDY EVALUATION}

The quality of each study was assessed independently by the two authors according to criteria outlined in the Cochrane Collaboration handbook. ${ }^{16}$ Each criterion-Selection bias, Performance bias, Attrition bias and Detection bias-was scored from 1 to 3 , the highest score for an individual trial being 12. Differences in trial quality scores were resolved by discussion. Data were extracted independently before being collated. Trial outcomes were summarised into the three categories listed above. Because of diverse outcomes and a relatively small number of trials examining any particular outcome, no quantitative summary measures for the outcomes were possible, and a metaanalysis was not performed.

\section{Results}

TRIALS INCLUDED/EXCLUDED

Seven randomised controlled trials that evaluated the use of computers in the treatment of hypertension were identified (table 1 ) ${ }^{17-23}$ The outcomes that were measured were diverse, with most of the trials examining more than 


\begin{tabular}{|c|c|c|c|c|c|c|c|}
\hline \multirow[b]{2}{*}{ Intervention } & \multirow[b]{2}{*}{ Role of computer } & \multirow[b]{2}{*}{$\begin{array}{l}\text { Intervention } \\
\text { aimed at }\end{array}$} & \multirow[b]{2}{*}{$\begin{array}{l}\text { Randomised } \\
\text { by }\end{array}$} & \multirow[b]{2}{*}{$\begin{array}{l}\text { Analysed } \\
\text { by }\end{array}$} & \multicolumn{3}{|c|}{ Trial favours computer? } \\
\hline & & & & & $\begin{array}{l}\text { Patient } \\
\text { uptakel } \\
\text { administration }\end{array}$ & $\begin{array}{l}\text { Physician } \\
\text { performance }\end{array}$ & Blood pressure control \\
\hline $\begin{array}{l}\text { (a) Computer reminder to } \\
\text { GP } v \text { (b) letter to patient } v \\
\text { (c) nurse telephone call to } \\
\text { patient }\end{array}$ & $\begin{array}{l}\text { Generated reminder to GP to } \\
\text { check BP until reading was } \\
\text { recorded }\end{array}$ & $\begin{array}{l}\text { Doctor (a) } \\
\text { Patient (b } \\
\text { and c) }\end{array}$ & Family & Patient & Yes & N/A & No \\
\hline $\begin{array}{l}\text { Computer generated feedback } \\
v \text { education programme } v \\
\text { both } v \text { neither }\end{array}$ & $\begin{array}{l}\text { Generated monthly feedback } \\
\text { reports on individual patients for } \\
\text { physician, containing } \\
\text { identification, age, date of last } \\
\text { visit, and latest BP }\end{array}$ & Doctor & Practice & Patient & Yes & Yes & No \\
\hline $\begin{array}{l}\text { Computer reminder to GP } v \\
\text { usual care }\end{array}$ & $\begin{array}{l}\text { Generated automatic reminder to } \\
\text { GP to check BP of patients }\end{array}$ & Doctor & Patient & Patient & Yes & N/A & Yes \\
\hline
\end{tabular}

\begin{tabular}{|c|c|c|c|c|c|c|c|}
\hline $\begin{array}{l}\text { Computer generated feedback } \\
v \text { usual care }\end{array}$ & $\begin{array}{l}\text { Produced feedback sheet per } \\
\text { patient for doctor containing: } \\
\text { (a) chart of diastolic BP } v \text { time } \\
\text { (b) intra- and interpractice } \\
\text { percentile ranking based on } \\
\text { diastolic BP } \\
\text { (c) commentary on treatment } \\
\text { prescribed by doctor }\end{array}$ & Doctor & Practice & Practice & 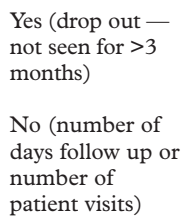 & N/A & $\begin{array}{l}\text { Yes (number of days } \\
\text { at }<90 \mathrm{~mm} \mathrm{Hg} \\
\text { diastolic for new } \\
\text { patients) } \\
\text { No (diastolic } \mathrm{BP} \text { ) }\end{array}$ \\
\hline $\begin{array}{l}\text { Data processed by central } \\
\text { computer and sent to special } \\
\text { care practices } v \text { usual care }\end{array}$ & $\begin{array}{l}\text { Registers data from hypertensive } \\
\text { patients, processes into surveys, } \\
\text { and returns surveys to } \\
\text { participating practices }\end{array}$ & Doctor & Practice & Patient & Yes & N/A & Yes \\
\hline $\begin{array}{l}\text { Computer held records } v \\
\text { standard hospital notes }\end{array}$ & $\begin{array}{l}\text { Allowed doctor to record clinical } \\
\text { information in structured format }\end{array}$ & Doctor & Patient & Patient & N/A & Yes & N/A \\
\hline $\begin{array}{l}\text { Computer generated } \\
\text { treatment recommendations } \\
v \text { usual physician care }\end{array}$ & $\begin{array}{l}\text { Generated drug type and dose } \\
\text { recommendations to physician }\end{array}$ & Doctor & Patient & Patient & N/A & No & No \\
\hline
\end{tabular}

one outcome. Patient uptake/administration was evaluated in five trials, four of which reported improvement using a computer. ${ }^{17-19}{ }^{21}$ Physician performance was evaluated in three trials, two of which reported improvement using a computer. ${ }^{18}{ }^{22}$ Control of blood pressure was evaluated in six trials, two of which reported improvement using a computer. ${ }^{1921}$

Three comparative studies that did not fulfil our criteria for inclusion in the review were identified. ${ }^{24-26}$ These studies used a matched control, ${ }^{24}$ before-after, ${ }^{25}$ or longitudinal design ${ }^{26}$ respectively and assessed a total of six outcomes.

A further 29 papers were identified that did not fulfil the inclusion criteria. These either (a) used a computer in some way in the treatment of hypertension in a non-randomised study, or (b) described the development of a number of different computer systems that assist in the management of patient data or offer the physi- cian advice on how to treat hypertension. A list of these references is available from the authors on request.

QUALITY ASSESSMENT

All trials were of similar methodological quality, with none scoring more than eight according to Cochrane quality criteria (table 1). The $\kappa$ statistic of between-rater agreement was 0.24 . All seven trials scored 1 on Selection bias (randomisation method not specified or little or no effort made) and 3 on Performance bias (no co-interventions permitted). All except one $\operatorname{trial}^{18}$ scored 1 on Attrition bias either because of not reporting losses to follow up or achieving follow up of less than $80 \%$. All except two trials ${ }^{2123}$ scored 1 on Detection bias because of either subjective outcome measures or non-blinding of outcome assessors. Additionally, cluster randomisation (randomising by practice/family but analysing by patient) 
may have affected outcomes in three of the trials. ${ }^{17}{ }^{18}{ }^{21}$ In one of these studies, ${ }^{17}$ however, the authors tested for any effect by analysing data from a randomly selected patient from each family unit and found that although the differences between intervention and control group patients were slightly reduced, the conclusions remained unchanged.

\section{EFFECTS ON PATIENT ADMINISTRATION}

Uptake

In two trials in which a reminder for the doctor was generated by computer, the percentage of patients in the computer group with a blood pressure recorded in their notes increased by $10 \%(95 \% \text { CI } 6 \%, 13 \%, \mathrm{p}<0.001)^{17}$ and $18 \%$ $(95 \% \text { CI } 0,36 \%, \mathrm{p}<0.05)^{19}$ respectively when compared with the control group. Barnett et $a l^{19}$ also found that the extent to which blood pressure measurement was either attempted or actually achieved was significantly greater in the computer group $(84 \%, 95 \%$ CI $73 \%, 92 \% v$ $25 \%, 95 \%$ CI $14 \%, 39 \%, \mathrm{p}<0.01)$.

Follow up

In a trial that investigated the effect of computer generated feedback for doctors ${ }^{18}$ the mean number of visits in a seven month follow up period made by patients with increased diastolic blood pressure and who required a follow up visit was $4.2(95 \% \mathrm{CI} 3.2,5.2)$ in the intervention group. This compared with 2.2 (95\% CI $0.6,3.8)$ visits in the same time period for patients in the usual care group $(p<0.05)$. The authors concluded that the feedback system led to doctors requesting patient appointments that would not have been otherwise scheduled.

McAlister et $a l^{20}$ found no difference in the mean number of visits per patient (10.8, $95 \%$ CI $9.2,12.4 v 12.4,95 \%$ CI $9.8,15.0$, $\mathrm{p}>0.05$ ) nor the number of days between first and last visits (199.3, 95\% CI 173.0, $225.6 v$ 167.0, 95\% CI 148.8, 193.3, p>0.05) between practices who received computer generated feedback and practices who continued with usual care. However, they found that drop out from regularly monitored treatment (not seen by a physician for three months or more at the conclusion of the trial) was significantly decreased in the computer group compared with usual care $(37.5 \%, 95 \%$ CI $34.8 \%, 40.2 \%$ v $42.1 \%, 95 \%$ CI $39.0 \%, 45.2 \%, \mathrm{p}<0.03)$.

Van den Hoogen $^{21}$ reported that practices using a computerised hypertension monitoring system that registers and processes data from patients resulted in $76 \%(95 \% \mathrm{CI} 74 \%, 78 \%)$ of patients being under permanent surveillance, compared with 45\% (95\% CI 37\%, 52\%) of patients in usual care practices. ${ }^{21}$

\section{EFFECTS ON PHYSICIAN PERFORMANCE}

\section{Physician knowledge}

Dickinson et $a l^{18}$ examined the effect of an education programme by examining GP knowledge of general and specific patient management issues for hypertension. They used a factorial design in which physicians received either computer feedback, an education programme, both, or neither. Physicians in all groups improved their scores on re-testing, but
KEY POINTS

- Computers have the potential to improve the detection, treatment, and follow up of hypertension in the community.

- Few randomised controlled trials have assessed this potential.

- The trials included here reported an improvement in patient administration but not in physician performance or blood pressure control.

- Doctors' use of computers and software sophistication have increased and the impact on hypertension requires further study.

those in the education and combined computer/education groups improved significantly more than those who received no education $(22 \%$ mean improvement, $95 \%$ CI $13.5 \%$, $30.5 \%$ v $12 \%$ mean improvement, $95 \% \mathrm{CI}$ $6.1 \%, 17.9 \%, p=0.025)$. Physicians who received the education programme also performed significantly better than those who received the computer alone or no intervention on questions that examined information specifically provided by the programme $(82 \%$, $95 \%$ CI $78 \%, 86 \%$ v $75 \%$, 95\% CI $72 \%, 78 \%$, $\mathrm{p}<0.01)$.

\section{Recording information}

In a trial in which patient medical records were kept on either computer or standard notes, ${ }^{22}$ recording of 15 key items was significantly better in computer held records. The percentage of patients with no record of these 15 key symptoms in the computer group ranged from $0-2.2 \%$, and in the standard group from $16.2-$ $81.0 \%$. All differences were significant at $\mathrm{p}<0.001$. The same was true for family history of hypertension and smoking, with significantly fewer patients in the control group having this information recorded in their notes $(p<0.01)$. A record of a positive result was made in more patients in the computer group than the standard group in 12 of the 15 key symptoms, reaching significance for two (vertigo and depression, both $\mathrm{p}<0.001$ ).

Prescribing

Coe et $a l^{23}$ found that computer generated treatment recommendations did not provide any advantage over normal physician care. Drug prescribing patterns were similar in both groups, and slightly more patients in the computer group appeared to suffer side effects.

EFFECTS ON BLOOD PRESSURE CONTROL

Two studies reported a greater percentage of patients in the computer group having controlled blood pressure. Van den Hoogen ${ }^{21}$ reported that after 18 months, $70 \%(95 \%$ CI $68 \%, 72 \%)$ of patients in practices using a computerised hypertension monitoring system had a diastolic $\mathrm{BP}<95 \mathrm{~mm} \mathrm{Hg}$, compared with 56\% (95\% CI $49 \%, 63 \%)$ in the usual care practices. Barnett et $a l^{19}$ found that at 12 months follow up $51 \%$ (95\% CI 38\%, 64\%) of patients whose physicians received a computer generated 
reminder had either diastolic $\mathrm{BP}<100 \mathrm{~mm} \mathrm{Hg}$ or were receiving treatment for hypertension (actual blood pressure level attained was not reported), compared with 33\% (95\% CI 20\%, $47 \%)$ in the control group $(\mathrm{p}<0.05)$. At 24 months, this increased to $70 \%(95 \%$ CI $57 \%$, $81 \%)$ and $52 \%(95 \%$ CI $38 \%, 66 \%)$ respectively $(\mathrm{p}<0.05)$.

Conversely in the trial by McDowell et al of 8298 subjects in Canada, ${ }^{17}$ twice as many patients whose doctor was sent a computer generated reminder had an "elevated reading" compared with patients in control practices $(17.2 \%, 95 \%$ CI $13.1 \%, 21.3 \%$ v $8.1 \%, 95 \%$ CI $4.8 \%, 12.6 \%)$. However, "elevated reading" was not defined.

Two studies reported that computer generated feedback did not result in any further decrease in BP compared with usual care..$^{18} 20$ Of note, the computer programs used in these two trials were the most sophisticated of all the seven trials, and the feedback generated by the computers was detailed. Dickinson et $a l^{18}$ found that differences in patient uptake and physician knowledge were not translated into any advantage in BP control. There were no statistical differences between the control group and any of the intervention groups in average systolic and diastolic blood pressure changes. This was also true for the percentage of patients with controlled diastolic BP at the end of the study, and for the percentage of patients with improved systolic and diastolic BP over the study period. McAlister et $a l^{20}$ reported that all four subgroups of patients in the computer group seemed to experience greater decreases in diastolic BP compared with usual care patients, though none of these differences were significant. They did however report that newly detected hypertensives in the computer group had a significantly greater mean number of days per patient year at $<90 \mathrm{~mm} \mathrm{Hg}$ diastolic than control patients ( 323 days, $95 \%$ CI 300 , $367 v 258$ days, $95 \%$ CI 213, 304, p<0.03).

Lastly, when physicians were given computer generated prescribing advice, Coe et $a l^{3}$ reported no difference in the mean reductions in diastolic and systolic pressures for patients in the computer and usual care groups. The mean reductions were $13.4 \mathrm{~mm} \mathrm{Hg}$ (95CI\% 10.6, 16.2) and $14.5 \mathrm{~mm} \mathrm{Hg}(95 \% \mathrm{CI} 11.7,17.3)$ respectively for diastolic pressures and 19.5 $\mathrm{mm} \mathrm{Hg}(95 \mathrm{CI} \% 14.5,24.5)$ and $18.3 \mathrm{~mm} \mathrm{Hg}$ (95\% CI 11.7, 24.9) respectively for systolic pressures.

\section{Discussion}

From these results, it is still not certain whether computers have a favourable effect on the management of hypertension. The three outcome dimensions measured were patient administration, physician performance, and blood pressure control, with six of the seven trials examining more than one outcome. Patient uptake/administration was evaluated in five trials, four of which reported significant improvement using a computer. ${ }^{17-19}{ }^{21}$ Physician performance was evaluated in three trials, two of which reported improvement using a computer. ${ }^{1822}$ Control of blood pressure was evaluated in six trials, two of which reported improvement using a computer. ${ }^{19}{ }^{21}$ However, positive findings from two of the trials ${ }^{1821}$ should be regarded cautiously because the possible effects of cluster randomisation may have been responsible for the significant results found. If this was the case, the number of trials reporting improvement in each of the outcome measures would be: patient uptake/ administration, two of five; physician performance, one of three; control of blood pressure, one of six.

Two previous reviews that examined the effects of computers on patient care were more positive in their findings. ${ }^{8}$ A systematic review of computer use in general practice reported that all 21 studies examining clinician performance demonstrated an improvement in outcome. ${ }^{8}$ Another systematic review of CDSSs in a broad variety of health interventions has shown that improvements can occur in drug dose, clinical diagnosis, preventive care reminders, and quality assurance. ${ }^{9}$ However, both these reviews awarded higher trial quality scores to trials that randomised by practice, but neither review seemed to take account of possible exaggeration of results when outcomes were analysed by patient.

This systematic review does have limitations. Firstly, the effects of cluster randomisation may have contributed to the positive findings in two of the trials. ${ }^{18}{ }^{21}$ Secondly, the trials were all of similar quality according to Cochrane criteria and generally scored poorly on selection, attrition, and detection bias. Although this was partly because of inadequate or unclear reporting, it is known that inadequate methodological approaches are associated with bias in estimates of treatment effects. ${ }^{27}$ Thirdly, the outcomes chosen were diverse between the randomised controlled trials, and similar outcomes were frequently not measured in the same way; for example, different blood pressure thresholds were used to denote control of hypertension. ${ }^{20}{ }^{21}$ Fourthly, the review only contains a small number of trials, most of which measured multiple outcomes, which may lead to false positive conclusions concerning the effects of intervention because of the play of chance. ${ }^{28}$ Lastly, most of the computer systems and programs were unsophisticated and no true decision support systems were evaluated. For these reasons, and in the light of rapid development of software, studies that evaluate new computer technology are required.

Computers have been applied effectively in the management of other chronic diseases. Improvement in diabetes care has been reported in terms of data collection and interpretation, decision support, and education. ${ }^{29}{ }^{30} \mathrm{~A}$ prototype CDSS has been developed for asthma management, targeted at the primary care setting and based on British Thoracic Society guidelines. ${ }^{31}$ In anticoagulation management, a CDSS improved patient outcome in terms of level of control, frequency of review, and general acceptability. ${ }^{32}$ A CDSS has been piloted in lipid management, ${ }^{33}$ and expert systems have been developed for the treatment 
of heart failure ${ }^{34}$ and depression. ${ }^{35}$ It seems likely that computer use and CDSSs are going to be used in the context of chronic disease management with greater frequency in the future.

An estimated $92 \%$ of general practices in Britain are now computerised. ${ }^{5}$ In practices in the South West Region that are computerised, $98 \%$ of general practitioners use a computer at the time of consultation for accessing patient data and prescribing ( $C$ Watkins, personal communication based on an unpublished study). With both the level of computerisation in primary care and the degree of sophistication of software increasing, an opportunity exists for expansion in terms of physician education, patient choices and preferences, measurement of compliance with treatment, and ultimately the combination of probability estimates with patients' utilities in the form of decision analysis. ${ }^{36}$

With the rule of halves still operating in the $\mathrm{UK},{ }^{2}$ hypertension remains an important public health problem. Risk stratification as a means of identifying patients who would benefit most from treatment needs to pursued. Effective management of hypertension in primary care requires coordinated registration, recall, and review, ${ }^{6}$ all of which can be facilitated by computer.

This review shows that computers may have a favourable influence on the uptake and administration of patients in hypertension management. Computer use in this area should be encouraged, particularly with regard to case finding and follow up. The results presented here do not seem to support any benefit in using computers in terms of physician performance and blood pressure control in patients. However, there has been enormous development both in software sophistication and doctors' use of computers, and further evaluation is warranted. Health authorities should take notice of developments in computer software that will allow effective targeting of resources to patients who are most at risk, and general practices should find ways of increasing their usage of computers in the management of hypertension in their practice population.

We would like to thank Debbie Sharp, Tim Peters, and Christopher MacKintosh for comments on the manuscript and Frank Sullivan for help with identifying studies examining the use of computers in general practice.

Funding: AM funded by grant no RC016 from Wales Office of Research and Development for Health and Social Care. Conflicts of interest: none.

1 MacMahon S, Peto R, Cutler J, et al. Blood pressure, stroke, and coronary heart disease. Part 1 , prolonged differences in blood pressure: prospective observational studies corrected for the regression dilution bias. Lancet 1990;335:765-74.

2 Du X, Cruickshank JK, McNamee R, et al. Case-control study of stroke and the quality of hypertension control in north west England. BMF 1997;314:272-6.

3 Anderson KM, Odell PM, Wilson PWF, et al. Cardiovascular disease risk profiles. Am Heart f 1991;121:293-8. 4 Core Services Committee. Guidelines for the management of
mildly raised blood pressure in New Zealand. Wellington: Ministry of Health, 1995.

5 Department of Health. Computerisation in GP practices. Leeds: NHS Management Executive, 1993.

6 Tudor-Hart J. Hypertension: community control of high blood pressure. 3rd ed. Oxford: Radcliffe Medical Press, 1993.

7 pressure. 3rd ed. Oxford: Radcliffe Medical Press, 1993 . support in primary care. London: North Thames Regional support in primary care.

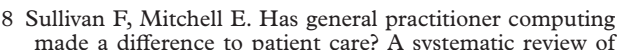
made a difference to patient care? A syste
published reports. BMF 1995;311:848-52.

9 Johnson M, Langton K, Haynes R, et al. Effects of computer-based clinical decision support systems on clinician performance and patients outcome. Ann Intern Med 1994;120:135-42.

10 Grimshaw JM, Russell IT. Effect of clinical guidelines on medical practice:a systematic review of rigorous evaluations. Lancet 1993;342:1317-22.

11 Sever P, Beevers G, Bulpitt C, et al. Management guidelines in essential hypertension: report of the second working party of the British Hypertension Society. BMF 1993;306: 983-7.

12 Joint National Committee on Detection $\mathrm{E}$ and $\mathrm{T}$ of HBP. The fifth report of the Joint National Committee on Dection, Evaluation and Treatment of High Blood Pressure (JNC V). Arch Intern Med 1993;153:154-83.

13 Subcommittee of WHO/ISH Mild Hypertension Liason Committee. Summary of 1993 World Health OrganisationInternational Society of Hypertension guidelines for the management of mild hypertension. BMF 1993;307:15416.

14 Meyers MG, Carruthers SG, Leenen FHH, et al. Recommendations from the Canadian Hypertension Society Consensus Conference on the Pharmacologic Treatment of Hypertension. Can Med Assoc f 1989;140:1141-6.

15 Dickerson K, Scherer R, Lefebvre C. Identifying relevent studies for systematic reviews. In: Chalmers I, Altman D, eds. Systematic reviews. London: BMJ Publishing Group, 1995:17-36.

16 Mulrow CD, Oxman AD. Cochrane Collaboration Handbook (updated 9 December 1996). In: The Cochrane Colaboration, ed. The Cochrane Library (database on disc and $C D R O M$ ). Issue 2 ed. Oxford: Update Software, 1996.

17 McDowell I, Newell C, Rosser W. A randomized controlled trial of computerized patient reminders for blood pressure screening in primary care. Med Care 1989;27:297-305.

18 Dickinson JC, Warshaw GA, Gehlbach SH, et al. Improving hypertension control: inpact of computer feedback and physician education. Med Care 1981;19:843-54.

19 Barnett GO, Winickoff RN, Morgan MM, et al. A compterbased monitoring system for follow-up of elevated blood pressure. Med Care 1983;21:400-9.

20 McAlister N, Covvey H, Tong C, et al. Randomised controlled trial of computer assisted management of hypertension in primary care. $B M \mathcal{F} 1986 ; 293: 670-4$.

21 van den Hoogen JPH, van Ree JW. Preventive cardiology in general practice: computer-assisted hypertension care. $\mathcal{F}$ Human Hypertens 1990;4:365-7.

22 Bulpitt CJ, Beilin LJ, Coles EC, et al. Randomised controlled trial of computer-held medical records in hypertensive patients. BMf 1976;1:677-9.

23 Coe F, Norton E, Oparil S, et al. Treatment of hypertension by computer and physician- a prospective controlled study. fournal of Chronic Disease 1977;30:81-92.

24 McInnes GT, McGhee SM. Delivery of care for hypertension. F Human Hypertens 1995;9:429-33.

25 Brownbridge G, Evans A, Fitter M, et al. An interactive computerized protocol for the management of hypertension:effects on the general practitioner's clinical behaviour. F Roy Coll Gen Pract 1986;36:198-202.

26 Kenkre J, Drury VWM, Lancashire RJ. Nurse management of hypertension clinics in general practice assisted by a computer. Fam Pract 1985;2:17-22.

27 Schulz KF, Chalmers I, Hayes RJ, et al. Empirical evidence of bias:dimensions of methodological quality associated of bias:dimensions of methodological quality associated
with estimates of treatment in controlled trials. $\mathscr{F A M A}$ with estimates of

28 Collins R, Peto R, Gray R, et al. Large-scale randomized evidence: trials and overviews. In: Weatherall DJ, Ledingham JGG, Warrel DA, eds. Oxford textbook of medicine. 3rd ed. Vol 1. Oxford: Oxford University Press, 1996:2132.

29 Lehmann ED, Deutsch T. Application of computers in diabetes care-a review. I. Computers for data collection and interpretation. Med Inf 1995;20:281-302.

30 Lehmann ED, Deutsch T. Application of computers in diabetes care-a review. II. Computers for decision support and education. Med Inf 1995;20:303-29.

31 Austin T, Iliffe S, Leaning M, et al. A prototype computer decision support system for the management of asthma. $\mathcal{F}$ Med Syst 1996;20:45-55.

32 Fitzmaurice D, Hobbs FDR, Murray ET, et al. Evaluation of computerized decision support for oral anticoagulation management based in primary care. $\mathrm{Br} f \mathrm{~F}$ en Pract 1996;46:533-5.

33 Hobbs FDR, Delaney BC, Carson A, et al. A prospective controlled trial of computerised decision support for lipid management in primary care. Fam Pract 1996;13:133-7.

34 Perlini S, Piepoli M, Marti G, et al. Treatment of chronic heart failure: An expert system advisor for general practitioners. Acta Cardiol 1990;45:365-78.

35 Selmi PM, Klein MH, Greist JH, et al. Computeradministered cognitive-behavioral therapy for depression. Am F Psychiatry 1990;147:51-6.

36 Dowie J. "Evidence-based", "cost-effective" and "preference-driven" medicine: decision analysis based medical decision making is the pre-requisite. Fournal of Health Service Research Policy 1996;1:104-13. 